\title{
Pengaruh Teknik Vulva Hygiene terhadap Jumlah Kuman Vulva pada Ibu Nifas di BPM Kota Bandar Lampung
}

\author{
Nelly Indrasari ${ }^{1}$, Purwati $^{2}$ \\ ${ }^{1}$ Jurusan Kebidanan, Politeknik Kesehatan Tanjungkarang, \\ ${ }^{2}$ Jurusan Keperawatan, Politeknik Kesehatan Tanjungkarang \\ Email: nellyindrasari@yahoo.com
}

\begin{abstract}
Effect of Vulva Hygiene Technique On The Number Of Germs In Postpartum Mother in BPM Bandar Lampung City. The case of maternal mortality in Bandar Lampung city in 2013 is 19 cases, in 2014 there are 7 cases and all died during childbirth and there are 19 cases of maternal death by 2015 (Profile of Lampung Province Health Office 2014). Research Objectives to Detect the Influence of Vulva Hygiene Technique on Number of Vulva Germs In Nifas Mother In BPM Bandar Lampung City Year 2016. This research method using quasiexperiment design. This study compares between treated groups and control groups. Treatment group 1 was treated with vulvar hygiene by using 1 cotton, group 2 using 3 kinds of cotton, group 3 using 5 cotton and control group without treatment. Population in this research is mother Nanyang checking his health at BPM in Bandar Lampung city at the time of research. The sample of respondent's research is 120 . Data collection with Teradata is done as much as 1 time then done culture and examination in a local laboratory. Data were processed and analyzed by independent T-test. The result showed that the average number of germs was 2277,37 germs (95\% CI 7140,59$38402,16)$ with standard deviation 65553,94 germs. The lowest number of germs and pathogen bacteria still $0.35 \%$ of respondents on the vulva hygiene of a cotton with a duration of 26 days. The result of analysis with cruciate Wallis test is 3,498. Looking at the statistics of the table by looking at the Chi-square table, for df (degrees of freedom) $=3$ and the significance level $(\alpha)=5 \%$, then obtained statist table 2.32. Because of the count statistic $(2.32>0.321)$, then Ho accepted, or no significant difference (significant). The research unit can utilize and apply vulva hygiene technique with antiseptic, so it can prevent the occurrence of infection in the postpartum mother.
\end{abstract}

Keywords: Vulva hygiene, Total germ, Postpartum

Abstrak: Pengaruh Teknik Vulva Hygiene terhadap Jumlah Kuman Vulva pada Ibu Nifas di BPM Kota Bandar Lampung. Kasus kematian ibu di Kota Bandar Lampung tahun 2013 terdapat 19 kasus, pada tahun 2014 terdapat 7 kasus dan semuanya meninggal masa nifas dan terdapat 19 kasus kematian ibu pada tahun 2015 disebabkan oleh infeksi nifas (Profil Dinas Kesehatan Provinsi Lampung 2015). Tujuan Penelitian untuk Mengetahui Pengaruh Teknik Vulva Hygiene Terhadap Jumlah Kuman Vulva Pada Ibu Nifas Di BPM Kota Bandar Lampung Tahun 2016. Metode penelitian ini dengan menggunakan desain quasi eksperimen. Penelitian ini membandingkan antara kelompok yang mendapat perlakuan dan kelompok kontrol. Kelompok perlakuan 1 diberikan perlakuan vulva hygien dengan menggunakan 1 kapas, kelompok 2 menggunakan 3 kapas, kelompok 3 mengunakan 5 kapas serta kelompok kontrol tanpa perlakuan. Populasi dalam penelitian ini adalah ibu nifas yang memeriksakan kesehatannya di BPM di wilayah Kota Bandar Lampung pada saat penelitian. Sampel penelitian responden sejumlah 120. Pengumpulan data dilakukan sebanyak 1 kali kemudian dilakukan kultur dan pemeriksaan di laboratorium daerah. Data diolah dan di analisis dengan uji T independen. Hasil penelitian didapat rata-rata jumlah kuman adalah 2277,37 kuman (95\% CI 7140,59-38402,16) dengan standar deviasi 65553,94 kuman. Jumlah kuman terendah dan masih didapatnya kuman patogen $0,35 \%$ responden pada vulva hygiene satu kapas dengan lama masa nifas 26 hari. Hasil analisis dengan uji kruskal wallis adalah 3,498. Melihat statistik tabel dengan melihat tabel Chi-square, untuk df (derajat kebebasan) $=3$ dan tingkat signifikansi $(\alpha)=5 \%$, maka didapat statistk tabel 2,32. Karena statistik hitung (2,32>0,321), maka Ho diterima, atau tidak ada perbedaan yang nyata (siqnifikan). Diharapkan tempat penelitian dapat memanfaatkan dan mengaplikasikan teknik vulva hygiene dengan kapas anti septik sebanyak 5 kapas, sehingga dapat mencegah terjadinya infeksi pada ibu nifas.

Kata kunci: Vulva hygiene , Jumah kuman, Ibu nifas 
AKI di Indonesia masih tertinggi di Negara ASEAN yaitu AKI di Malaysia 41 per 100.000 kelahiran hidup, Singapura 6 per 100.000 , Thailand 44 per 100.000 kelahiran hidup, Vietnam 160 per 100.000 , Filipina 170 per 100.000 kelahiran hidup. Berdasarkan dataSurvey Demografi dan Kesehatan Indonesia (SDKI) dan sensus penduduk kecendrungan angka kematian ibumeningkat dari 228/100.000 kelahiran hidup $(\mathrm{KH})$ menjadi 359/100.000 KH padatahun 2010-2015.

Tiga penyebab utama Angka Kematian Ibu di Indonesia dalam bidang obstetri adalah perdarahan (45\%), infeksi (15\%) dan pre eklampsia (13\%) (DepKes RI, 2007).

Infeksi nifas merupakan morbiditas dan mortalitas bagi ibu pasca bersalin. Derajat komplikasi masa nifas bervariasi. Asuhan masa nifas diperlukan dalam periode masa nifas karena merupakan masa kritis baik ibu maupun bayi. Diperkirakan bahwa 60\% kematian ibu akibat kehamilan terjadi setelah persalinan dan $50 \%$ kematian masa nifas terjadi dalam 24 jam pertama pasca persalinan.

Pada masa nifas dapat terjadi gangguan pada ibu seperti infeksi, sehingga menimbulkan kondisi yang berbahaya dan berujung kematian pada ibu. Di Indonesia sendiri setiap satu jam ada dua orang ibu yang meninggal dunia karena komplikasi pada masa nifas, penyebab kematian ibu yang paling besar adalah perdarahan $28 \%$ dan infeksi sebanyak $11 \%$.

Faktor komplikasi obstetrik diantaranya adalah infeksi nifas pada pertolongan persalinan yang tidak mengindahkan syarat-syarat asepsis antisepsis.

Diperkirakan bahwa 60\% kematian ibu akibat kehamilan terjadi setelah persalinan, dan 50\% kematian masa nifas terjadi dalam 24 jam pertama. Secara nasional menurut Purwanto (2001), angka kejadian infeksi pada kala nifas mencapai $2,7 \%$ dan $0,7 \%$ diantaranya berkembang kearah infeksi akut. Dengan demikian asuhan pada masa nifas diperlukan dalam periode ini karena merupakan masa kritis baik ibu maupun bayinya (Saifuddin, 2001).

Kasus kematian yang ada di Provinsi Lampung tahun 2014 berdasarkan laporan dari kabupaten terlihat bahwa kasus kematian ibu (kematian ibu pada saat hamil, saat melahirkan dan nifas) seluruhnya sebanyak 130 kasus dimana kasus kematian ibu nifas sebanyak 55 kasus. Kasus kematian ibu di Kota Bandar Lampung tahun 2013 terdapat 19 kasus, pada tahun 2014 terdapat 7 kasus dan semuanya meninggal masa nifas dan terdapat 19 kasus kematian ibu pada tahun 2015, disebabkan infeksi nifas (Profil Dinas Kesehatan Provinsi Lampung 2015).

Masa nifas (puerperium) adalah masa sesudah persalinan yang dimulai setelah plasenta lahir dan berakhir ketika alat-alat kandungan kembali seperti keadaan sebelum hamil yang berlangusng kira-kira 6 minggu. Infeksi nifas adalah infeksi pada dan melalui traktus genitalis setelah persalinan.

Perawatan organ-organ reproduksi sangatlah penting. Jika tidak dirawat dengan benar dapat menyebabkan berbagai macam akibat yang dapat merugikan, misalnya infeksi dan penyakit kelamin seperti ISR, ISK, vaginitis, keputihan (Kusmiran, 2011).

Alat genital wanita terdapat mekanisme pertahanan tubuh berupa bakteri yang menjaga kadar keasaman $\mathrm{pH}$ vagina. Normalnya angka keasaman pada vagina berkisar antara 3,8-4,2. Sebagian besar, hingga 95\% adalah bakteri laktobasilus dan selebihnya adalah bakteri patogen. Data penelitian tentang kesehatan reproduksi wanita menunjukkan $75 \%$ wanita didunia pasti menderita keputihan, paling tidak sekali seumur hidup dan $45 \%$ diantaranya mengalami keputihan sebanyak dua kali atau lebih (Pribakti, 2008).

Berdasarkan penelitian Hubungan Pengetahuan dengan Sikap Mahasiswi Tingkat I Tentang Vulva Hygiene Di Akbid Mamba'ul 'Ulum Surakarta Tahun 2015. Hasil penelitian didapatkan karakteristik responden berdasarkan sumber informasi menunjukkan mayoritas didapatkan dari media cetak (buku, koran, majalah), yaitu sebanyak 30 responden $(57,7 \%)$. Pengetahuan mahasiswi tentang vulva hygiene mayoritas dalam kategori cukup, yaitu sebanyak 37 responden $(71,2 \%)$ dan sikap vulva hygiene mayoritas dalam kategori baik, yaitu sebanyak 32 responden (61,5\%). Hasil analisis data tersebut terdapat hubungan antara pengetahuan dengan sikap mahasiswi tentang vulva hygiene dibuktikan dengan nilai Zhitung adalah 2,292 dan $\mathrm{p}=0,020$. Sedangkan Ztabel yaitu 1,96 dan $\alpha=0,05$. Hal ini berarti bahwa Zhitung $>$ Ztabel atau 2,292 > 1,96 atau $p=0,020<\alpha=0,05$ (Sri Wahyuni 2015).

Vulva hygiene adalah membersihkan vulva dan daerah sekitarnya pada pasien wanita yang sedang nifas atau tidak dapat melakukannya sendiri. Pasien yang harus istirahat di tempat tidur (misalnya, karena hipertensi, pemberian infus, section caesarea) harus dimandikan setiap hari dengan pencucian daerah perineum yang dilakukan dua kali sehari dan pada waktu sesudah 
selesai membuang hajat. Meskipun ibu yang akan bersalin biasanya masih muda dan sehat, daerah daerah yang tertekan tetap memerlukan perhatian serta perawatan protektif.

Setelah ibu mampu mandi sendiri (idealnya, dua kali sehari), biasanya daerah perineum dicuci sendiri dengan menggunakan air dalam botol atau wadah lain yang disediakan khusus untuk keperluan tersebut. Penggantian tampon harus sering dilakukan, sedikitnya sesudah pencucian perineum dan setiap kali sehabis ke belakang atau sehabis menggunakan pispot.

Prevalensi kasus infeksi nifas di Provinsi Lampung mengalami peningkatan dari $0.02 \%$ pada tahun 2010 menjadi $0.04 \%$ tahun 2011 dan pada tahun 2012 tetap sebesar $0.04 \%$ (Riskesdas 2012). Kasus penyakit infeksi nifas tahun 20122013 yang ditemukan di Provinsi Lampung sebanyak 1.030 kasus, dimana Lampung Barat 103 (10\%) kasus, diikuti Pringsewu 102 (9,8\%) kasus, Way kanan $98(9,5 \%)$ kasus. Metro 94 $(9,1 \%)$ kasus, Bandar Lampung $89(8,6 \%)$ kasus, Lampung Selatan $89(8,6 \%)$ kasus, Lampung Utara 81 (7,8\%) kasus, Mesuji 79 (7,6\%) kasus, Lampung Timur 76 (7,3\%) kasus, Tanggamus 72 $(6,9 \%)$ kasus, Lampung Tengah 67 (6,5\%) kasus, Pesawaran $53(5,1 \%)$ kasus, Tulang Bawang 51 $(4,9 \%)$ kasus, Tulang Bawang Barat $50(4,8 \%)$ kasus dan Kabupaten Pesisir Barat $17(1,6 \%)$ kasus. (Dinas Kesehatan Provinsi Lampung, 2012).

Dari teori-teori vulva hygiene yang ada peneliti melihat belum ada kesepakatan tentang teknik vulva hygiene yang baku begitu juga dengan jumlah kapas yang digunakan. Masingmasing mengunakan cara yang berbeda-beda. Begitu juga pengamatan peneliti di lapangan ada petugas yang mengunakan satu kapas, tiga kapas, lima kapas dan masih juga ada yang langsung periksa dalam tidak melakukan usapan kapas.

Berdasarkan permasalahan tersebut maka penelitian ini bertujuan untuk mengetahui Pengaruh Teknik Vulva Hygiene Terhadap Jumlah Kuman Vulva Pada Ibu Nifas di BPM Kota Bandar Lampung Tahun 2016?".

\section{METODE}

Metode penelitian ini dengan
menggunakan desain quasi eksperimen.
Penelitian ini membandingkan antara kelompok
yang mendapat perlakuan dan kelompok kontrol.
Kelompok perlakuan 1 diberikan perlakuan vulva
hygiene dengan menggunakan 3 kapas dtt,
kelompok 2 menggunakan 5 kapas dtt, kelompok

3 menggunakan 1 kapas dtt serta kelompok kontrol tanpa perlakuan. Populasi dalam penelitian ini adalah ibu nifas yang memeriksakan kesehatannya di BPM di wilayah Kota Bandar Lampung.

Sampel penelitian ini adalah ibu nifas yang memeriksakan kesehatannya ke BPM di Kota Bandar Lampung. Berdasarkan perhitungan diatas didapatkan sejumlah 16 responden tiap kelompok, dengan perbandingan $1: 1$, sehingga keseluruhan responden sejumlah 64 dibulatkan jadi 70 respoden. Agar karakteristik sampel tidak menyimpang dari populasinya, maka penentuan kriteria masing-masing kelompok sampel ditentukan dengan kriteria inklusi sampel ; Ibu nifas usia 21-40 tahun, memeriksakan kesehatan di BPM diwilayah Kota Bandar Lampung tahun 2016, dan Kriteria eksklusi sampel kasus Wanita yang belum memiliki anak, usia $<21->40$ tahun, tidak memeriksakan kesehatannya di BPM di wilayah Kota Bandar Lampung tahun 2016. Analisis data yang digunakan dalam penelitian ini adalah statistik deskriptif dan analisis data dengan statistik inferensial.

\section{HASIL}

\section{A. ANALISIS UNIVARIAT}

Analisis yang dilakukan terhadap setiap variabel dari hasil penelitian yang akan menghasilkan distribusi dan presentasi dari tiap variabel pada penelitian yang dilakukan terhadap 70 sampel berdasarkan sumber data primer di BPM Desi Angraini, BPM Nurhasanah, BPM Ketut Dani, BPM Nurmala Dewi dan BPM Lia Maria Kota Bandar Lampung. Berikut ini hasil analisis univariat dari masing-masing variabel. Distribusi rata-rata yang diperoleh dari hasil pemeriksaan pada kelompok perlakuan vulva hygiene dengan 1 kapas, kelompok perlakuan vulva hygiene dengan 3 kapas, kelompok perlakuan vulva hygiene dengan 5 kapas dan kelompok kontrol (tanpa perlakuan) dengan jumlah sampel 70 ibu nifas 10 hari sampai dengan 40 hari adalah sebagai berikut:

Tabel 1. Distribusi Jumlah Kapas dengan Jumlah Kuman Usapan Vulva pada Ibu Nifas

\begin{tabular}{lcccc}
\hline \multicolumn{1}{c}{ Variabel } & Mean & SD & $\begin{array}{c}\text { Min/ } \\
\text { Maks }\end{array}$ & 95\% CI \\
\hline Jumlah koloni & 2277,37 & 65553.94 & $9-$ & 7140,59 \\
kuman & & & 300000 & 38402,16 \\
\hline
\end{tabular}


Hasil analisis didapat rata-rata jumlah kuman adalah 2277,37 kuman (95\% CI 7140,5938402,16) dengan standar deviasi 65553,94 kuman. Jumlah kuman terendah 9 kuman dan jumlah terbanyak 300000 kuman. Dari hasil estimasi interval dapat disimpulkan bahwa $95 \%$ di yakini bahwa rata-rata jumlah kuman adalah diantara 7140,59 kuman sampai dengan 38402,16 kuman.

Tabel 2. Distribusi Jumlah Kapas Usapan Vulva dengan Lama Masa Nifas, Jumlah Kuman, dan Jenis Kuman pada Ibu Nifas

\begin{tabular}{cccc}
\hline $\begin{array}{c}\text { Jumlah } \\
\text { kapas }\end{array}$ & $\begin{array}{c}\text { Rata-rata } \\
\text { Lama } \\
\text { Hari Nifas }\end{array}$ & $\begin{array}{c}\text { Total } \\
\text { Jumlah } \\
\text { Kuman }\end{array}$ & $\begin{array}{c}\text { Pengelompokan } \\
\text { Kuman (Patogen } \\
\text { dan Apatogen) \% }\end{array}$ \\
\hline 0 & 18 & 18394 & 0.470 \\
\hline 1 & 26 & 4074 & 0.35 \\
\hline 3 & 21 & 30110 & 0.444 \\
\hline 5 & 19 & 37223 & 0.611 \\
\hline
\end{tabular}

Berdasarkan Tabel 2 terlihat pada vulva hygiene dengan satu kapas, bahwa untuk rata-rata hari nifas terlama 26 hari untuk total jumlah kuman dan jumlah responden yang pada kulturnya didapat kuman patogen terendah pada satu kapas yaitu: 4074 jumlah kuman dan 0,35\% responden yang ditemui ada kuman patogen pada hasil kultur.

\section{B. ANALISIS BIVARIAT}

Analisis bivariat dilakukan untuk mengetahui perbedaan antara variabel independen (jumlah kapas) dengan variabel dependen (jumlah kuman) menggunakan uji kruskal wallis untuk mengetahui apakah ada perbedaan jumlah kuman yang nyata diantara keempat kelompok teknik vulva hygiene.

Tabel 3. Distribusi Jumlah Kapas dengan Jumlah Kuman Usapan Vulva pada Ibu Nifas

\begin{tabular}{lccccc}
\hline $\begin{array}{c}\text { Jumlah } \\
\text { Kapas }\end{array}$ & n & $\begin{array}{c}\text { Mean } \\
\text { Rank }\end{array}$ & df & $\begin{array}{c}\boldsymbol{p} \text { - } \\
\text { value }\end{array}$ & $\begin{array}{c}\text { Statistik } \\
\text { hitung } \\
\mathbf{2 , 3 2}\end{array}$ \\
\hline $\begin{array}{llllll}\text { Tanpa } \\
\text { kapas }\end{array}$ & 17 & 39,00 & \multirow{2}{*}{3} & 0,321 & 0,321 \\
\cline { 1 - 2 } Kapas 1 & 16 & 27,56 & & & \\
\cline { 1 - 2 } Kapas 3 & 18 & 39,08 & & & \\
\cline { 1 - 2 } Kapas 5 & 19 & 35,66 & & & \\
\cline { 1 - 2 } Total & 70 & & & & \\
\hline
\end{tabular}

Berdasarkan Tabel 3 terlihat bahwa untuk mean rank 39,00 untuk tanpa kapas, mean 27,56 untuk yang satu kapas, 39,08 untuk yang tiga kapas dan 35,66 untuk yang lima kapas.
Hasil analisis dengan uji kruskal wallis adalah 3,498. Melihat statistik tabel dengan melihat tabel Chi-square, untuk df (derajat kebebasan) $=3$ dan tingkat signifikansi $(\alpha)=5 \%$, maka didapat statistk tabel 2,32. Karena statistik hitung $(2,32>0,321)$, maka Ho diterima.

Terlihat bahwa pada kolom asymp. Sig/asymptotice adalah 0,321 atau probabilitas diatas 0,05 maka Ho diterima, atau tidak ada perbedaan yang nyata (siqnifikan) diantara jumlah kuman. Dengan kata lain jumlah kapas 1, kapas 2, kapas 3 dan non kapas boleh dikatakan sama.

\section{PEMBAHASAN}

\section{A. UNIVARIAT}

Berdasarkan Tabel 2 terlihat pada vulva hygiene dengan satu kapas, bahwa rata-rata pada hari ke-26 post partum total jumlah kuman pada kultur responden didapat kuman patogen terendah pada satu kapas yaitu: 4074 jumlah kuman dan $0,35 \%$ responden yang ditemui ada kuman patogen pada hasil kultur.

Demam nifas atau dengan kata lain morbiditas puerperalis meliputi demam dalam masa nifas oleh sebab apapun. Menurut commitee on maternal walfare (Amerika Serikat) definisi morbiditas puerperalis ialah kenaikan suhu sampai $38^{\circ} \mathrm{C}$ atau lebih selama 2 hari dalam 10 hari pertama postpartum, dengan mengecualikan hari pertama. Suhu harus diukur dari mulut sedikit-sedikitnya 4 kali sehari (Lusa, 2011).

Penelitian ini dilakukan pada respoden dengan masa post partum antara hari 10 sampai hari ke 40 post partum ditemukan jumlah kuman terendah dan masih didapatnya kuman patogen $0,35 \%$ responden pada vulva hygiene satu kapas dengan lama masa nifas 26 hari. Keadaan ini kemungkinanan disebabkan oleh pada teknik vulva hygiene dengan satu kapas rata-rata lama masa nifasnya lebih lama di bandingkan dengan teknik vulva hygeine dengan tanpa kapas (0), dengan tiga kapas (3) dan lima kapas (5).

\section{B. BIVARIAT}

Hasil analisis dengan uji kruskal wallis adalah 3,498. Melihat statistik tabel dengan melihat tabel Chi-square, untuk df (derajat kebebasan) $=3$ dan tingkat signifikansi $\alpha=5 \%$, maka didapat statistk tabel 2,32. Karena statistik hitung $(2,32>0,321)$, maka Ho diterima.

Terlihat bahwa pada kolom asymp. Sig/asymptotice adalah 0,321 atau probabilitas 
diatas 0,05 maka Ho diterima, atau tidak ada perbedaan yang nyata (siqnifikan) diantara jumlah kuman. Dengan kata lain jumlah kapas 1, kapas 2, kapas 3 dan non kapas boleh dikatakan sama.

Vulva hygiene merupakan suatu tindakan untuk memelihara kebersihan organ kewanitaan bagian luar (vulva) yang dilakukan untuk mempertahankan kesehatan dan mencegah infeksi (Ayu, 2010).

Menjaga kesehatan berawal dari menjaga kebersihan. Hal ini juga berlaku bagi kesehatan organ-organ seksual. Cara memelihara organ intim tanpa kuman dilakukan sehari-hari dimulai bangun tidur dan mandi pagi. Alat reproduksi dapat terkena sejenis jamur atau kutu yang dapat menyebabkan rasa gatal atau tidak nyaman apabila tidak dirawat kebersihannya. Mencuci vagina dengan air kotor, pemeriksaan dalam yang tidak benar, penggunaan pembilas vagina yang berlebihan, pemeriksaan yang tidak higienis, dan adanya benda asing dalam vagina dapat menyebabkan keputihan yang abnormal. Keputihan juga bisa timbul karena pengobatan abnormal, celana yang tidak menyerap keringat, dan penyakit menular seksual (Kusmiran Eni, 2011).

Fatmawati Manurung, Perilaku Ibu Pascasalin dalam Melakukan Vulva Hygiene di Wilayah Kerja Puskesmas Muliorejo Kecamatan Sunggal Kabupaten Deli Serdang Tahun 2011. Hasil penelitian menunjukkan bahwa sebagian besar ibu pascasalin berpengetahuan baik sebanyak 36 orang $(78,3 \%)$ dan sebagian kecil berpengetahuan cukup sebanyak 10 orang $(21,7 \%)$. Berdasarkan sikap sebagian besar ibu pasca salin dalam melakukan vulva hygiene mempunyai sikap positif sebanyak 44 orang $(95,7 \%)$ dan sebagian kecil mempunyai sikap negatif sebanyak 2 orang (4,3\%).Berdasarkan tindakan sebagian besar ibu pascasalin dalam melakukan vulva hygiene sebanyak 46 orang (100\%) melakukan vulva hygiene.

Menurut peneliti hasil yang diperoleh tidak ada perbedaan yang nyata (signifikan) diantara jumlah kuman. Dengan kata lain jumlah kapas 1, kapas 2, kapas 3 dan non kapas boleh dikatakan sama. Ini tidak sejalan dengan teori Vulva hygiene. Dimana langkah-langkahnya: Informed consent, Menempatkan alat-alat ke dekat pasien, pintu atau jendela ditutup bila perlu pasang sampiran, Menyiapkan posisi pasien dorsal recumbent, pakaian bagian bawah dikeatas-kan (perhatikan cairan yang keluar dari vagina pasien), pasang pengalas bagian bawah bokong pasien, dekatkan kom berisi kapas lembab pada pasien, letakkan bengkok ke dekat bokong/ perineum pasien, mencuci tangan dan keringkan, memakai sarung tangan, ambil 5 kapas lembab, bersihkan labia mayora kiri dan kanan dengan menggunakan kapas lembab dari atas ke bawah sampai bersih (satu kapas satu kali usapkan) buang kapas ke dalam bengkok, dengan tangan kiri petugas (jari telunjuk dan ibu jari) buka labia mayora pasien kemudian bersihkan labia minora kiri dan kanan dengan menggunakan kapas lembab dari atas ke bawah sampai bersih, kemudian bersihkan bagian vestibulum, perineum, dan anus (selama melakukan vulva hygiene perhatikan keadaan vagina), buang kapas ke dalam bengkok, rapihkan pasien, dengan memakaikan kembali pakaian dalam dan pembalutnya, rapihkan pasien serta alat dan cuci tangan dan keringkan dengan handuk bersih.

Tidak sejalannya hasil penelitian dengan teori di karenakan:

1. Penelitian ini pada pengambilan kultur hanya satu kali, tidak dua kali (sebelum tindakan dan setelah tindakan diambil lagi).

2. Sampel juga masa nifasnya rentang waktunya terlalu lama 30 hari, kemungkinan akan lebih baik bila 10 hari jadi pada pasca nifas 30 hari sampai dengan 40 hari.

3. Ditemukan jumlah kuman terendah dan masih didapatnya kuman patogen $0,35 \%$ responden pada vulva hygiene satu kapas dengan lama masa nifas 26 hari. Keadaan ini kemungkinanan disebabkan oleh teknik vulva hygiene dengan satu kapas rata-rata lama masa nifasnya.

4. Kapas yang di gunakan hanya bebas kuman tetapi tidak mematikan kuman

5. Variabel yang dinilai hanya teknik vulva hygiene seharusnya variabel faktor-faktor jumlah kuman di vulva juga menjadi perhatian.

6. Kapas hanya di usapkan tanpa menentukan derajat penekanannya

Perlu dilakukan penelitian lanjutan dengan pengambilan kultur dua kali (sebelum tindakan dan setelah tindakan diambil lagi) kemudian di lihat perbedaannya. Pada sampel masa nifasnya rentangannya10 hari yaitu pada pasca nifas 30 hari sampai dengan 40 hari. Kapas yang di gunakan sebaiknya mematikan kuman. Diteliti juga variabel faktor-faktor jumlah kuman di vulva. Kapas yang di usapkan ditentukan derajat penekanannya. 


\section{SIMPULAN}

Berdasarkan hasil penelitian dan pembahasan mengenai Pengaruh Teknik Vulva Hygiene terhadap Jumlah Kuman Vulva pada Ibu Nifas di BPM Kota Bandar Lampung Tahun 2016, maka dapat diambil kesimpulan sebagai berikut:

1. Hasil analisis didapat rata-rata jumlah kuman adalah 2277,37 kuman (95\% CI 7140,59 - 38402,16) dengan standar deviasi 65553,94 kuman. Jumlah kuman terendah 9 kuman dan jumlah terbanyak 300000 kuman. Dari hasil estimasi interval dapat disimpulkan bahwa 95\% di yakini bahwa rata-rata jumlah kuman adalah diantara 7140,59 kuman sampai dengan 38402,16 kuman.

2. Penelitian ini ditemukan jumlah kuman terendah dan masih didapatnya kuman patogen $0,35 \%$ responden pada vulva hygiene satu kapas dengan lama masa nifas 26 hari. Keadaan ini kemungkinanan disebabkan oleh teknik vulva hygiene dengan satu kapas rata-rata lama masa nifasnya lebih lama di bandingkan dengan teknik vulva hygiene yang lain.

3. Hasil analisis dengan uji kruskal wallis adalah 3,498. Melihat statistik tabel dengan melihat tabel Chi-square, untuk df ( derajat kebebasan $)=3$ dan tingkat signifikansi $(\alpha)=$ $5 \%$, maka didapat statistk tabel 2,32. Karena statistik hitung $(2,32>0,321)$, maka Ho diterima.

\section{SARAN}

Berdasarkan hasil penelitian, maka saran yang dapat penulis berikan setelah mengadakan penelitian adalah sebagai berikut:

1. Bagi Ibu Nifas

Penelitian ini diharapkan dapat meningkatkan pengetahuan ibu tentang vulva hygiene, sehingga proses pemulihan masa nifas dapat berjalan lancar dan tidak menyebabkan komplikasi pada ibu dan bayi.

2. Bagi BPM Desi angraini, BPM Nurhasanah, BPM Ketut Dani, BPM Nurmala Dewi dan BPM Lia Maria dapat memanfaatkan dan mengaplikasikan teknik vulva hygiene dengan anti septik, sehingga dapat mencegah terjadinya infeksi pada ibu nifas .

3. Bagi Institusi Pendidikan Prodi Kebidanan Tanjung karang, Hasil penelitian ini diharapkan dapat dijadikan sebagai wacana untuk menambah pengetahuan bagi mahasiswi Prodi Kebidanan Tanjung karang khususnya dalam mata kuliah asuhan nifas.

4. Bagi Peneliti Selanjutnya

Penelitian ini diharapkan dapat menjadi bahan masukan, sehingga dapat menjadi bahan pertimbangan untuk melakukan penelitian yang berkaitan. Saran yang dapat di sampaikan : Penelitian ini dilanjutkan dengan pengambilan kultur dua kali (sebelum tindakan dan setelah tindakan diambil lagi) kemudian di lihat perbedaannya. Pada sampel masa nifasnya rentangannya10 hari yaitu pada pasca nifas 30 hari sampai dengan 40 hari. Kapas yang di gunakan sebaiknya mematikan kuman. Diteliti juga variabel faktor-faktor jumlah kuman di vulva. Kapas yang di usapkan ditentukan derajat penekanannya.

\section{DAFTAR PUSTAKA}

Ayu, HK. 2010. Aplikasi Praktis Asuhan Keperawatan Keluarga. Jakarta: Sagung Seto.

Departemen Kesehatan Republik Indonesia. 2011. Profil Kesehatan Republik Indonesia Tahun 2011. Jakarta : Depkes RI.

Dinas Kesehatan Provinsi Lampung. 2011. Profil Kesehatan Provinsi Lampung Tahun 2011. Bandar Lampung: Dinkes Lampung.

Lusa. 2011. Infeksi Nifas. Dikutip dari: http://www.lusa.web.id/infeksi-masa-nifas/ (Diakses pada 24 Februari 2016).

Kementerian Kesehatan RI. 2014. Prosedur Pemeriksaan Bakteriologi Klinik. Jakarta.
Kusmiran, Eny. 2011. Kesehatan Reproduksi Remaja dan Wanita. Jakarta: Salemba Medika.

Manurung, Fatmawati. 2011. Perilaku Ibu Pascasalin dalam Melakukan Vulva Hygiene di Wilayah Kerja Puskesmas Muliorejo Kecamatan Sunggal Kabupaten Deli Serdang Tahun 2011. Skripsi, Fakultas Keperawatan, Universitas Sumatera Utara. http://repository.usu.ac.id/handle/1234567 89/27258 (Diakses pada 24 Februari 2016). Pribakti. 2008. Tips dan Trik Merawat Organ Intim. Yogyakarta: Pustaka Banua. 